УДК 33

DOI $10.21661 / \mathrm{r}-462249$

\title{
И.С. Новичков
}

\section{ОСОБЕННОСТИ РЫНКА ТУРИСТИЧЕСКОГО СТРАХОВАНИЯ И ПУТИ ПОВЫШЕНИЯ ЕГО ОБЪЁМОВ В РОССИИ}

Аннотация: в данной статье представлено исследование Российской и зарубежной практики страхования, были изложены варианты повышения объёмов рынка, а также подавления психологического барьера российских туристов.

Ключевые слова: страхование, туризм, услуги, потребление, курортные зоны, страховые риски.

\section{I.S. Novichkov}

\section{CHARACTERISTICS OF TRAVEL INSURANCE MARKET} AND THE WAYS TO INCREASE ITS VOLUME IN RUSSIA

Abstract: this article presents the study of the Russian and foreign insurance practices, outlines options for increasing the volume of the market, as well as suppressing the psychological barrier of the Russian tourists.

Keywords: insurance, tourism, services, consumption, resort areas, insurance risks.

Согласно статистике последних лет, наблюдается положительная динамика количества несчастных случаев за рубежом и при путешествиях в пределах Российской Федерации, в том числе тяжелых - включая летальный исход и необходимость репатриации тела к постоянному месту жительства. При данном происшествии, туристу будет необходима квалифицированная медицинская помощь здесь стоит вспомнить о наличии услуг туристического страхования.

К сожалению, большинство граждан Российской Федерации не пользуются услугами страховых компаний перед выездом за рубеж. Исследование данной проблемы очень важно для повышения уровня этики туризма, что в свою очередь приведет к повышению количества страхований жизни на случай болезни или же 
летального исхода, а также к уменьшению количества страховых случаев. В Российской Федерации активное развитие рынка туристического страхования началось 10-15 лет назад, и это все еще сказывается на просвещенности граждан относительно страховых полисов.

Спецификой туристского рынка является явное преобладание услуг. Товары и услуги в данной сфере могут быть потреблены при условии перемещения потребителя в место производства, в то время как обычные товары и услуги готовы к употреблению после перемещения к потребителю.

Также для рынка туристических услуг характерно неравномерное распределение спроса в течении года (к примеру, для активного отдыха на горнолыжных курортах) и широкий диапазон эластичности спроса, что привносит свои нюансы. Стоит учитывать, что в силу потребления услуг туристами на месте временного проживания, структуру потребления нужно рассматривать как совокупность обязательных, специфических и дополнительных потребностей.

Выезжая за рубеж, турист попадает в непривычные для него условия, что является большим стрессом для организма, особенно при долгих перелетах в страны, радикально отличающиеся по погодным условиям. По официальной статистике Ростуризма, наиболее популярными из стран дальнего зарубежья для отдыха стали Турция, Финляндия, Эстония. Из стран ближнего зарубежья - Абхазия и Казахстан.

Однако, по количеству страховых случаев лидируют иные страны - Турция, Египет и Таиланд. Большинство страховых компаний признают Турцию бесспорным лидером по количеству страховых случаев. Наиболее частые диагнозы - гастроэнтерит, которым обозначают весьма широкий список, начиная от диареи и заканчивая дизентерией, простуды и травмы. Последнее появляется в связи с низкой культурой туризма, что уже было упомянуто в начале статьи. Крайняя неосторожность в активном отдыхе приводит к растяжениям, переломам, вывихам. Также нельзя не отметить частое появление страховых случаев, 
связанных с перегревом. Погодные условия Турции довольно существенно отличаются от российских, в связи с чем клиенты страховых компаний часто получают ожоги, солнечные удары, проявляются симптомы гипертермии.

Наблюдается положительная динамика и в количестве страховых случаев, связанных с авариями. Многие туристы берут в аренду автомобили, но ситуация на турецких дорогах оказывается для них слишком непривычной, в связи с чем многие аварии имеют летальный или же очень тяжелый исход. В данном случае необходимо увеличивать минимальный стаж вождения для сдачи автомобиля в аренду, что практически невозможно в связи с потерей прибыли для компании арендодателя и высокой конкуренцией на рынке проката автомобилей.

Также, многие туристические компании упоминают Египет, как страну, неблагоприятную в плане страховых случаев. Климат и антисанитария вызывают большое количество заражений различными инфекциями. Предотвратить это возможно за счет проведения инструктажей перед выездом туристов за рубеж, а также за счет сознательного выбора гражданами более надежных мест размещения а так же добровольным медицинским страхованием, включающим в себя вакцинацию.

Аналогично неблагополучны в данном плане страны Африки, ОАЭ, Таиланд. Таиланд традиционно показывает большое количество травм, сопряженных с автомобильными авариями. Это связано с большой популярностью скутеров, а также с их легкодоступностью в плане аренды. Также, в Таиланде регистрируется большое количество отравлений в связи с низким уровнем санитарных норм и кардинальных различий в культуре приготовления и употребления пищи.

Меньший процент страховых случаев показывают европейские страны, такие, как Италия, Германия, Франция, Швейцария. Это обусловлено основными типами отдыха, которыми пользуются туристы - отпуск с целью покупок, осмотра достопримечательностей и гастрономические туры. Данные виды ту- 
ризма менее травмоопасны, нежели активный горнолыжный отдых или пляжный, где легко можно пострадать от перегрева и прочих факторов окружающей среды.

При расчете страхового полиса стоит учитывать возраст страхуемого. Так, в последнее время увеличилось количество людей старше 55-60 лет, которые путешествуют на дальние расстояния. Смена климата, еды, многочасовые перелеты или поездки на поездах не проходят бесследно для пожилых людей. Для данных граждан стоит подбирать наиболее щадящие климатические условия и стараться уменьшить длительность перелетов, а также проводить полное обследование перед выездом за рубеж.

Совсем иная группа выезжающих - младенцы или дети возрастом до 3-х лет вместе со своими родителями. Часто происходит заражение данной категории лиц вирусными инфекциями и тяжелыми заболеваниями по причине отсутствия минимального набора прививок, необходимых в данном возрасте. Особенно часто страховые случаи с участием детей происходят в вышеупомянутых странах Египет, Турция, Тайланд, а также в странах с низким уровнем санитарных норм. Этого можно избежать, выбирая проверенные места временного пребывания и сделав все необходимые прививки, прежде чем будет приобретена путевка.

Крайне остро стоит проблема страхования при туризме в пределах Российской Федерации. По данным ВСС (Всероссийский союз страховщиков) менее трех процентов россиян, путешествующих в пределах РФ, оформили страховку в 2016 году.

«По статистике страхового сообщества, количество застрахованных человекопоездок в 2016 году составило 14,2 миллиона. Это мы подсчитали общее число российских туристов за рубежом и по России. Есть данные, что по России в 2016 году путешествовало порядка 60 миллионов человек, и только 1,7 миллиона туристов были застрахованы на время поездки» - председатель комитета по вопросам страхования в туризме Всероссийского союза страховщиков (ВСС) Юлия Алчеева. При этом ВСС подтвердил, что количество застрахованных внутренних туристов постепенно растет. Если в 2012 году со страховкой путешествовали по 
стране 728,6 тысячи человек, то в 2016 году их количество увеличилось почти в 2,4 раза и превысило 1,7 миллиона человек.

Нередко страховые случаи возникают по вине туроператоров, выбравших более дешевый пансион в угоду прибыли и популярности тура, а не качеству. Двух-, трехзвездочные отели могут не иметь кондиционеров в номерах, что приведет к гипотермии, или же возможны не надлежащие санитарные условия. Неверный выбор сопровождающего группу также может привести к неприятным исходам.

К сожалению, и в нынешнее время туристические агентства относятся к страхованию жизни потребителя с пренебрежением, выбирая неблагополучные страховые компании. В то же время, данный выбор может ухудшить репутацию туристического агентства в глазах потребителя, что приведет к падению популярности и понижению конкурентоспособности на рынке туристических услуг. Также, неудачный выбор страхового агентства для туристической фирмы может обернуться весьма весомой потерей прибыли.

Одна из наиболее весомых проблем, затормаживающих темпы роста и развития страхового рынка Российской Федерации - менталитет рядового гражданина, укрепившийся в сознании постсоветский уклад, при котором вся ответственность за причиненный и полученный ущерб во время внутреннего отдыха несет сам турист. Особенно актуально этот вопрос встает для горнолыжных курортов России, когда любая травма катающихся приводит к снижению популярности курортов и оттоку туристов. Для решения данной проблемы Дмитрий Медведев поручил правительству до конца 2017 года проработать вопрос о введении обязательного страхования жизни и здоровья туристов на горнолыжных курортах, как было сообщено на сайте кабинета Министров.

В связи с увеличением рисковых факторов, связанных с террористическими угрозами в Турции и восточном направлении, а также осложнением отношений с Евросоюзом и Украиной, особенно актуальна роль туристических страховых полисов добровольного страхования. Повышение количества маркетинговых 
компаний и доступность информации в сети Интернет могут значительно повысить грамотность населения в данном вопросе, что увеличит оборот внутреннего рынка туристического страхования в России. Также стоит обратить внимание на просветительскую деятельность в иных источниках, как то телевидение или печатные материалы, для большего охвата аудитории.

\section{Сиисок литературы}

1. Федеральный Закон «Об организации страхового дела в Российской Федерации». - Ст. 10. - П. 4.

2. Гвозденко А.А. Основы страхования: Учебник. - М.: Финансы и статистика, 2013. - 304 с.

3. Юлдашев Р.Т. Страхование туристов // Страховой бизнес: Словарь-справочник. - М.: Анкил, 2014. - С. 671. - 832 с.

4. Электронная газета страхового рынка [Электронный ресурс]. - Режим доступа: http:/www.insurance-info.ru/?cat=8 (дата обращения: 23.05.2017).

5. Лента.Ру, 27 февраля 2017 г. Названы наиболее распространенные болезни российских туристов [Электронный ресурс]. - Режим доступа: http://www.insur-info.ru/press/123921/ (дата обращения: 23.05.2017).

Новичков Илья Сергеевич - студент ФГОБУ ВО «Финансовый университет при Правительстве Российской Федерации», Россия, Москва.

Novichkov Ilya Sergeevich - student at FSBEI of HE "Financial University under the Government of the Russian Federation", Russia, Moscow. 